\title{
Changes in Water, Carbohydrates and Nitrogen Contents of Pea Plants during the Pathogenesis of Fusarium solani f. sp. pisi Infection
}

\author{
Malati MAJUMDAR* and S. P. RAYCHAUDHURI** \\ Malati Majumdar·S. P. Raychaudhuri : 根腐病感染過程における \\ 水分, 炭水化物, 窒素化合物の含量の変化
}

\begin{abstract}
Various disorders, in growth as well as metabolic process, occur due to infection. Carbohydrate and total nitrogen content are the factors which alter during pathogenesis in many cases. Accumulation of phenolic substances is a common effect of pathogenic injury, and this may be regarded as a defence reaction. ${ }^{1)}$ Pea plants of ten get stunted when Fusarium solani infection takes place in early stage. Again the pathogen being a root rotting one, hindrance in water uptake is an obvious effect, causing ultimately alteration in moisture content of the host. In the preasent investigation attempts were, therefore, made to compare the changes in dry weight, moisture content, carbohydrate content, total nitrogen percentage and total phenolic content between the healthy and the diseased plants. A commonly grown susceptible pea variety Bonneville was taken for the experiments. Inoculation was done by keeping the seeds in spore suspension $\left(4 \times 10^{5}\right.$ spores $\left./ \mathrm{ml}\right)$ for 5 days and then transplanting in vermiculites. Seeds soaked in sterile water and then transplanted in vermiculite served as control. Plants were kept at $25 \mathrm{C}$. Sampling was done after 5, 10, 15 and 18 days of inoculation. For both healthy and infected lots the plant parts were sampled in five groups viz., primary root, secondary root, foot, stem and leaves. Samples were washed, blotted, immediately packed in oil paper bags and weighed. These were then dried at $80 \mathrm{C}$ till constant weight and dry weights were determined. Dried samples were powdered for estimation of total nigrogen, carbohydrate and total phenol content. Total nitrogen was estimated by microKjeldahl's method. ${ }^{2)}$ Sugar was extracted with $80 \%$ alcohol at $80-85 \mathrm{C}$ for 30 minutes and then clarified by the method described in A. O. A. C.2) Non-reducing sugars were hydrolysed to reducing sugars by mixing with $0.5 \mathrm{~N} \mathrm{HCl}$ and then keeping in boilling water bath for half an hour. These were then neutralised with $0.5 \mathrm{~N} \mathrm{NaOH}$. Starch was extracted with $9.2 \mathrm{~N}$ and then $4.2 \mathrm{~N} \mathrm{HClO}_{4}$ by adding $2 \mathrm{ml}$ of the reagents while stirring constantly and keeping as such for $15 \mathrm{~m}$. Somogyi's method ${ }^{3)}$ was followed for sugar and starch estimation. Total phenolic content was assessed colorimetrically following Bray and Thorpe ${ }^{4)}$ and was expressed as moles of phenol. Decrease in dry weight, due to infection, in all the plant parts at all intervals after

* Indian Agricultural Research Institute, New Delhi-110012, India

** Haryana Agricultural University, Hissar 125004, Haryana, India

1) Farkas, G. L. and Kiraly, Z. (1962). Phytopath. Z. $44: 105.2$ 2) Anonymous (1960). Official methods of analysis of the Association of official Agricultural Chemists (A. O. A. C), Washington, D. C. 9th Edition. 3) Somogyi, M. (1952). J. Biol. Chem. 195:19. 4) Bray, H. G. and Thorpe, W. V. (1954). Meth. Biochem. Anal. 1:27. 5) Cruickshank, I. A. and Perrin, D. R. (1964). In J. B. Harborne (Ed.), Biochemistry of phenolic compounds. Academic Press, London and New York.
\end{abstract}




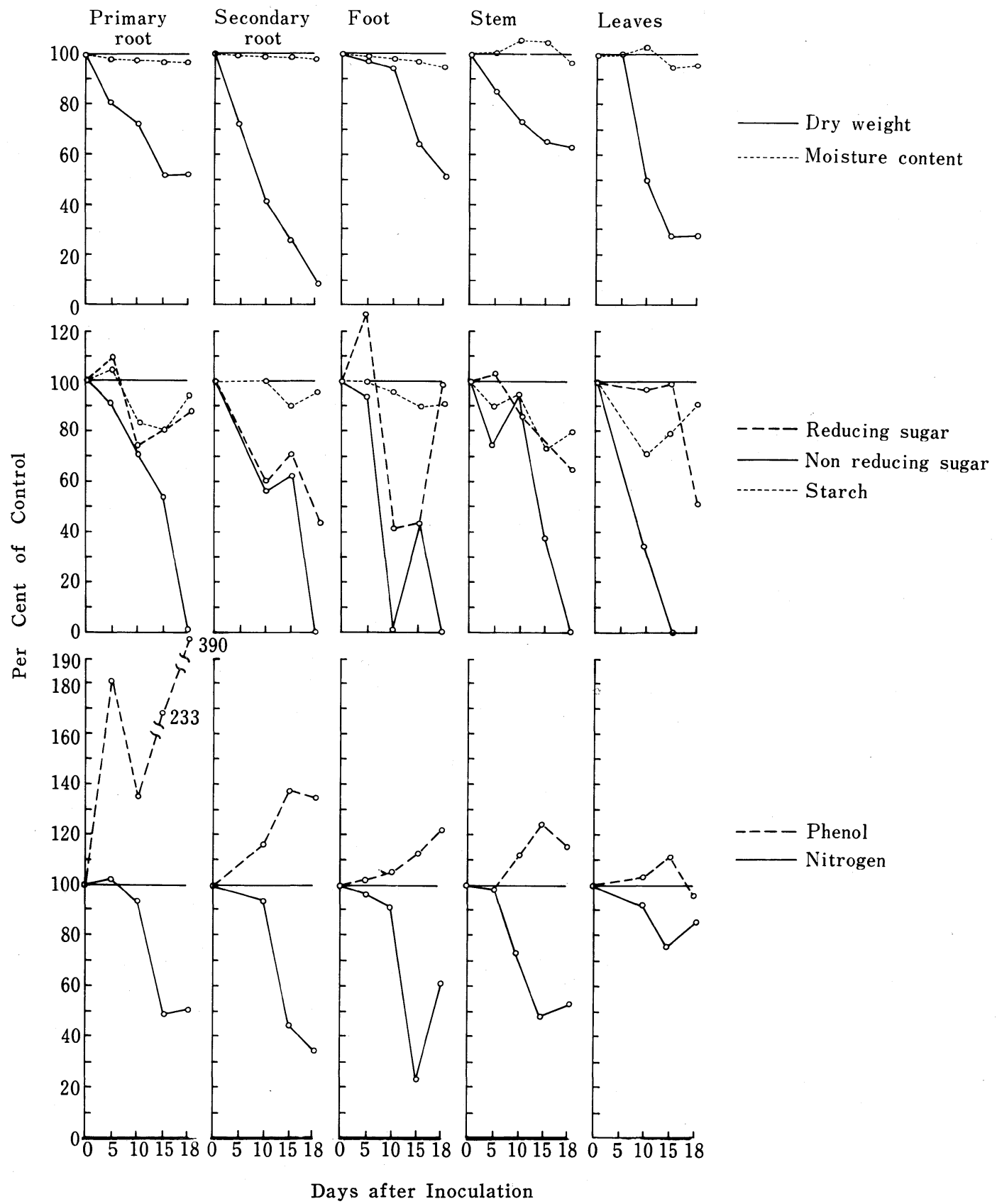

Fig 1. Changes in dry weight, moisture content, carbohydrate content, total nitrogen percentage and total phenolic content due to Fusarium solani f. sp. pisi infection in pea plants 
inoculation and moisture content in almost all cases is evident from Fig. 1. The overall disturbances in the metabolic processes, due to infection, might have lead to some change in the growth. Assessment of carbohydrate from all parts of plant at various stages of infection revealed reduction in contents of reducing and nonreducing sugars, and starch in almost all cases, which also has bearing on decreased dry weight due to infection. The pathogen, being a root rotting one, decayed the root system thus hindering the water uptake, which ultimately caused less water content of the infected tissue. It is clear from the figure that the response, due to infection, in total nitrogen percentage is different from that of total phenol content.

The formar was found to decrease at the infection site, i. e. the primary aud secondary root and the foot region and to increase in stem and leaves, in almost all stages of pathogenesis, while the latter behaved in a reverse way. Although post-infectional accumulation of phenolic substances at the infection site has been observed in many cases $^{1)}$ and presumed to play an important role in the defence mechanism and symptom development ${ }^{5)}$, more phenolics were present in the diseased susceptible tissue, and had a positive correlation with symptom development, at least in the present case.

The Senior author is grateful to the Project Director, Nuclear Research Laboratory, IARI, for providing necessary facilities for this work.

(Received June 22, 1976) 